Maiko Noguchi

\title{
Communicating a Biography: A Comparison of the Maghribi-Andalusi and Mashriqi Sources on al-Qāọi 'lyāọ
}

\section{Introduction}

The compilation of biographies was one of the most common and important intellectual activities in the premodern world. In Islam, a large number of biographical dictionaries devoted to poets, 'ulamā', a yān (notable people), and others have been produced over the centuries and continue to be written even today. ${ }^{1}$ We can ascertain various things from biographies, not only about the individual being described but also about the particular group(s) of people to which they belonged. As such, many modern studies of medieval biographies have been produced to help further knowledge of aspects of social and intellectual history.

However, when researching the life of an individual, we often come across multiple sources. These sources are sometimes contradictory in nature, even though they relate to the same person. In such cases, how should we make sense of the differences between the texts? Which information - if any - should we consider more reliable or plausible? Examining the communication and development or alteration of biographical information over time and space may help us answer these questions, and this paper will do so through a case-study of al-Qādī 'Iyād (d. 544 H/1149 CE). Al-Qāọī 'Iyāḍ was one of the most famous jurists of the Mālikì law-school and a renowned hadìth scholar in the medieval Maghrib. His life was included in a number of biographical dictionaries after his death not only in the Islamic West but also in the East, despite the fact that he never made the hajj, visited the Mashriq, or had many teachers or students there. This is rather interesting because, although the people of the Mashriq might not have generally shown an interest in someone who had limited involvement with them, a certain

1 However, pre-modern biographical literature has little in common with modern (Cooperson 2010). On historical writing in Islam, see Guo 2010. On research analyzing 'ulama ', see Humphreys 1991, 187-208.

Note: This work was supported by the Sasakawa Scientific Research Grant from the Japan Science Society and the Japan Society for the Promotion of Science. 
number of Mashriqi biographers included such Maghribis in their works. ${ }^{2}$ And these biographies of 'Iyād are full of interesting evidence, such as how information was communicated and the spread of the intellectual influence of an 'älim between the Islamic West and East. Nevertheless, modern scholars have shown little interest in this issue. Thus, in this paper, I will explore how the biography of al-Qāḍi 'Iyāḍ was communicated and constructed in the Mashriq through a comparison of dictionaries written in the Maghrib and al-Andalus. María José Hermosilla has covered this issue to some extent, but many important Mashriqi sources are ignored in her article. ${ }^{3}$

In this paper, I have classified the sources as either Maghribi-Andalusi or Mashriqi, according to the place where their writers were active. As there are a significant number of dictionaries containing a biography of al-Qāọi 'Iyāọ, this paper will, with just a few exceptions, only use those sources that were composed up to the end of the 8th/14th century. This is because, following that period, the information contained within the sources on al-Qāḍi 'Iyāḍ is wholly derivative.

\section{The life and career of al-Qāọī 'lyāọ}

Al-Qāọī 'Iyāọ, Abū al-Faḍl 'Iyāọ b. Mūsā al-Yaḥ̣ubī was born in Ceuta in 476 $\mathrm{H} / 1083 \mathrm{CE} .{ }^{4}$ He came from a distinguished family that traced its origins back to the Arabs of Yemen. His great-grandfather, 'Amrūn (or 'Amr), moved to Ceuta from Fez, the oldest town in the central Morocco, around the time of Ibn Abī 'Āmir (r. 368-392 H/978-1002 CE), the chief minister and de facto ruler of the Umayyad caliphate of Córdoba. 'Iyāḍ began his studies in his hometown under various prominent intellectuals, such as Abū 'Abd Allāh Muhammad b. 'Īsā al-Tamīmī (d. 505 H/1111 CE) and Abū 'Alī al-Ḥasan b. 'Alī al-Tāhartī (d. 501 H/1108 CE). ${ }^{5}$ In 507 $\mathrm{H} / 1113 \mathrm{CE}$, at the age of 31, he completed his studies in Ceuta and then crossed to

2 On the biographies of the Maghribis and Andalusis in the Mashriqi biographical dictionaries, there are several studies in the EOBA (Estudios onomástico-biográficos de al-Andalus) series published by CSIC since 1988.

3 Hermosilla 1978-79.

4 On his biography, there are not only many historical sources in Arabic but also studies in several other languages. Moreover, the monograph titled al-Ta'rîf bi-l-Qā to al-Qāḍi 'Iyāḍ") was written by his son, Muhammad, and the 11th/17th-century historian Shihāb al-Dīn al-Maqqarī (d. 1041 H/1632 CE) wrote Azhār al-riyāẹ fi akhbār 'Iyā d ("The Gardens' Flowers on Reports about 'Iyāḍ”). For modern studies on 'Iyāḍ, see the bibliography, below.

5 On al-Tamīmī, see 'Iyāḍ, al-Ghunya (1979), 99-115. On al-Tāhartī, see 'Iyāọ, al-Ghunya (1979), 204-206. 
al-Andalus to seek knowledge from scholars there, with support from the Almoravid sovereign of the time, 'Alī b. Yūsuf (r. 500-537 H/1106-1143 CE). ${ }^{6}$ After his arrival in al-Andalus, it is thought that he counted on the qā Hamdinn (d. 508 H/1114 CE), ${ }^{7}$ after which he studied law and hadith under famous scholars in Murcia, Córdoba, Almería, and Granada including a traditionist, Abū 'Alī al-Ṣadafī (d. 514 H/1120 CE), and a scholar of Arabic language and traditionist, Sirāj b. 'Abd al-Malik (d. 507 H/1113 CE). ${ }^{8}$ About a year later, he returned to his native town where he became a member of the consultative council (shūrā) after participating in an academic debate on Sahnūn's (d. 240 H/855 CE) al-Mudawwana ("The Corpus"). ${ }^{9}$ After this, he became a qā In Ceuta, he held that position for 19 years - from $515 \mathrm{H} / 1121 \mathrm{CE}$ to $531 \mathrm{H} / 1136 \mathrm{CE}$ and from $539 \mathrm{H} / 1145 \mathrm{CE}$ to $543 \mathrm{H} / 1148 \mathrm{CE}$ - though his time in Granada was either for only several months or for a year sometime in the period 531-532 H/1136-1138 CE. Just as his first rihla ("journey") to al-Andalus had been, so too were his appointment and dismissal as qā rulers; his dismissal as qā with the city's amīr, Tāshfīn b. 'Alī b. Yūsuf (future sovereign, r. 537-539 H/11431145 CE), and his reappointment as qā dī of Ceuta in 539 H/1145 CE was confirmed by Tāshfīn's son, the ruler Ibrāhīm (r. 539 H/1145 CE). ${ }^{10}$

Only a few sources describe how 'Iyāẹ spent his later years, but thanks to recent studies we now have an idea not only of his scholarly position at that time but also, to a certain extent, his political one. According to these, after Marrakesh, the Almoravid capital, was captured by the Almohads (524-668 H/1130-1269 CE)

6 The Almoravids (c. the second half of 5th century-541 H/11th century-1147 CE) was founded by the Șanhāja Berber tribes of the western region of the Sahara; they ruled the Maghrib and alAndalus and adopted the Mālikī school of law as their creed.

7 Al-Fath b. Khāqān (d. 529 H/1134 CE, see below for further details) conveys two letters written by the vizier Abū al-Qāsim b. al-Jadd (d. 515 H/1121-2 CE) which recommended 'Iyāọ to Ibn Hamdīn. One of them is a petition that Abū al-Qāsim wrote on behalf of the sovereign 'Alī $b$. Yūsuf. See al-Fatḥ b. Khāqān, Qalā'id al-iqyān (2010), 326-328. On Ibn Ḥamdīn, see 'Iyāạ, alGhunya (1979), 116-117.

8 On al-Ṣadafî, see 'Iyāọ, al-Ghunya (1979), 193-201. On Sirāj, see 'Iyāạ, al-Ghunya (1979), 261265.

9 According to Camilo Gómez-Rivas, this debate is a kind of rite of passage through which someone had to pass before they could be appointed to the shūrā. See Gómez-Rivas 2013, 326.

10 Muḥammad b. 'Iyāḍ, al-Ta'rīf (2009), 10-11. In addition to these, Shihāb al-Dīn al-Maqqarī conveys the poem which 'Iyāḍ composed when the latter was appointed qāọi of Dāy (a town of Tādlā region of central Morocco). It is said that this appointment was in $541 \mathrm{H} / 1146-7 \mathrm{CE}$, but Gómez-Rivas considers it happened in 543 H/1148 CE. See al-Maqqarī, Azhār al-riyāẹ (1980), 4: 267; Gómez-Rivas 2013, 326. 
in $541 \mathrm{H} / 1147 \mathrm{CE}$, the supporters of the former continued to resist the Almohads both in the Maghrib and al-Andalus. As such, during this period 'Iyād preached jihād against the Almohads in his Friday sermons in Ceuta. Later, though, he changed his view and, in another sermon, swore an oath of allegiance to them. Moreover, he was involved in issuing golden dinārs in Ceuta at that time. ${ }^{11}$ Therefore, he can be regarded as a central figure in this resistance, acting as if he were the ruler of the town. ${ }^{12}$ After finally conquering Ceuta, the Almohads took 'Iyād to Marrakesh; in some sources, it is claimed that he died there shortly after, in 544 H/1149 CE.

'Iyāḍ studied under various important members of the 'ulamā' and formed friendships with many of them in both his native town and al-Andalus. These included Ibn Hamdin and Ibn Rushd al-Jadd (d. 520 H/1126 CE), the most prominent Mālikî jurist of his day in the Islamic West, in addition to the aforementioned alȘadafî and Sirāj b. 'Abd al-Malik. From his biographical work focused on his teachers, al-Ghunya ("The Richness"), it is known that he was taught by around 100 teachers, and that they were not only from the Islamic West but also the East, with 'Iyād himself remaining in the Maghrib. ${ }^{13}$ As a result, he had significant influence on knowledge flow from al-Andalus to the Maghrib and was also instrumental in establishing the Mālikī school of law in that region. ${ }^{14} \mathrm{He}$ was a prolific writer, composing around 30 works during his lifetime. Among them a book of praise for the Prophet Muhammad based on the sciences of hadith, al-Shifä' bita'rīf ḥuqūq al-Muștafā ("Healing by Recognition of the Rights of the Chosen One”), a biographical dictionary on Mālikī 'ulamā', Tartīb al-madārik wa-taqrīb al-masālik li-ma'rifat a lām madhhab Mālik ("Organizing the Faculties and Revealing the Methods for Discovering the Signs of the School of Mālik”), and alGhunya are especially well-known. In addition to these, his son Muhammad compiled his father's fatwās into a volume entitled Madhāhib al-ḥukkām fì nawāzil alaḥkām ("Judges' Proceedings in Judicial Processes"), which also has been regarded as an important work. However, despite his significant impact on later Islam, information on his students is scarce, and according to modern scholars, only 10-12 students are known, in addition to his son Muhammad. ${ }^{15}$

11 On his sermons, see Jones 2013. On his dīnārs, see Kassis 1983; Fierro 2006. On the general situation at that time, Gómez-Rivas 2013, 327-328. On his scholarly position, see also Eggen 2018.

12 For the similar figures of his contemporaries, see Fierro 1994.

13 Thanks to the location of Ceuta, which is on the Mediterranean coast, he could study from the ' ' lamä' who came and stopped at the town. See 'Iyāḍ, al-Ghunya (1979).

14 Gómez-Rivas 2013, 323-324. 'Iyāḍ was also a hadìth scholar, and some modern scholars have referred to him as a man of letters. Cf. Shaqūr 1983.

15 Shawwāṭ 1999, 239-244; Jallāb 2009, 32-34. 


\section{Biographies of 'lyāọ}

\subsection{Maghribi and Andalusi sources ${ }^{16}$}

The earliest source from the Maghrib and al-Andalus with information on 'Iyāḍ is al-Fatḥ b. Khāqān's (d. 529 H/1134 CE) Qalā'id al-'iqyān wa-maḥāsin al-a'yān ("Golden Necklaces and the Virtues of Notable People"). Al-Fatḥ b. Khāqān was an anthologist who probably hailed from Jaén or Seville, and a contemporary of 'Iyāọ, and they were friends. ${ }^{17}$ Qalā'id al-iqyān is not, strictly speaking, a biographical dictionary but is instead an anthology of the works of famous persons such as princes and viziers, secretaries (kuttāb), qā dīs, fuqaha $\bar{a}$, poets, and men of letters. It covers around $80 \mathrm{men}$ in total, most of whom were contemporaries of the author. 'Iyāḍ himself was included among the "qā dịs and fuqahä"'. The article devoted to him within Qalā'id al-iqyān includes some of his poetry and letters, in addition to an appreciation of his various abilities. It is a rather unusual tome because it contains hardly any of the kind of information about individuals - such as dates of birth or death, birthplace, career, or teachers and students etc. - that is usually found in Arabic biographical dictionaries, and such is the case for the article on 'Iyāḍ. The information contained within it seems to have originated from 'Iyāḍ and the author himself, and it is likely to have been written while 'Iyāạ was alive, given the date of the author's death. ${ }^{18}$

A second biography was written by the man believed to have been 'Iyāḍ's only son, Abū 'Abd Allāh Muhammad (d. 575 H/1179-80 CE) ${ }^{19}$ He received most of his education from his father and was one of the students who helped keep his father's ideas alive. Muhammad was appointed qāộ̀ first of Dénia and then of Granada. As mentioned, he produced two main works related to his father: a

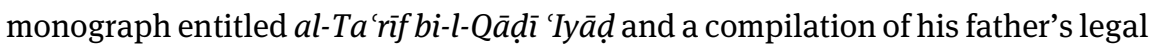

16 In this paper, I will consider the biographical dictionaries that contain an entry on 'Iyāḍ.

17 Ibn al-Abbār, al-Mu 'jam (2011), 374; Ibn 'Abd al-Malik, al-Dhayl (2012), 3: 444-445. Cf. Ben Cheneb/Pellat, “al-Fatḥ b. Muhammad b. 'Ubayd Allāh b. Khāḳān”, $E I^{2}$.

18 Al-Fatḥ b. Khāqān, Qalā'id al-iqyān (2010), 683-691. According to the description of the date, he compiled this work after 515 H/1121 CE. See al-Fatḥ b. Khāqān, Qalā’id al-iqyān (2010), 357, 361.

19 Though we have little information about Muhammad, Ibn Sharīfa, the editor of al-Ta' rîf, organized his biographies from the sources and listed them in the introduction (Muhammad $b$. 'Iyāọ, al-Ta 'rîf [2009], alif-shīn). Muhammad's date of birth is not known for certain, but it is said that he died in $575 \mathrm{H} / 1179-80 \mathrm{CE}$ when he was in his forties; therefore, he is likely to have been born around in the 520 s or $530 \mathrm{~s} \mathrm{H/mid} \mathrm{1120s} \mathrm{or} \mathrm{1130s} \mathrm{CE.} \mathrm{For} \mathrm{Muhammad's} \mathrm{biography,} \mathrm{see} \mathrm{Se-}$ rrano Ruano 2004. 
opinions entitled Madhāhib al-ḥukkām. While al-Ta'rīf is not a lengthy work, it records 'Iyāḍ's biography - including his origins and ancestors - his works - which include selected hadiths, Friday sermons, poetry, and the titles of about 20 works in total - and his teachers' names. ${ }^{20}$ Most of this information came, naturally, from 'Iyāọ himself, Muhammad's father. Moreover, it is perhaps noteworthy that some of 'Iyāḍ's poems were recorded by Muhammad newly; thus, the latter is regarded as one of the main sources for them, in addition to al-Fath $b$. Khāqān. ${ }^{21}$ Despite 'Iyāḍ’s reputation and influence among his contemporaries and posterity, Muhammad's monograph about his father was employed by only a very limited number of later biographers. It is thought that there was only one copy of this work, kept by one of Muhammad's descendant in Málaga. ${ }^{22}$

Although Muhammad should have had great knowledge about 'Iyāọ’s life, he was limited in the information he could record. This is at least partly because Muhammad was in a rather difficult situation when he was writing since his father had revolted against the dynasty - the Almohads - under which Muhammad himself had been appointed $q \bar{a} \bar{a}_{\bar{\imath}}{ }^{23}$ It has not proved possible to locate definitive information regarding this monograph's date of composition, although the phrase "the qāộ̀ Abū 'Abd Allāh Muhammad said...”' (qāla al-qāộ̀ Abū 'Abd Allāh Muhammad) appears at the beginning of the text, suggesting that he composed the monograph after he himself had been appointed $q \bar{a} d \underline{i}$, which probably occurred sometime in the early 570s H/ the late 1170s CE. ${ }^{24}$

20 In the introduction, Muhammad explained the reason behind compiling the book: his master (in the text, "sayyidi”, meaning 'my master') - who is mentioned as a sublime faqīh, perfect hâfiz, diligent Qur'ān reciter, though we have no specific information about him - asked him about his father, 'Iyāḍ, so he wrote it.

21 Two poems and a portion of the information originated from Muhammad's companions, and his cousin Abū 'Abd Allāh, among others.

22 Muhammad b. 'Iyāḍ, al-Ta'rîf (2009), lām. This information is based on that of al-Bunnāhī, which will be mentioned later.

23 Muḥammad b. 'Iyāạ, al-Ta'rīf (2009), kāf. See Gómez-Rivas 2013, 327-328.

24 Muhammad b. 'Iyāọ, al-Ta'rīf (2009), 3. According to Ibn 'Abd al-Malik al-Marrākushī, Muhammad took the position of $q \bar{a} d \bar{c}$ of Dénia before 570 H/1174-5 CE and then became the qã of Granada (Ibn 'Abd al-Malik, al-Dhayl [2012], 5: 242). Moreover, Muhammad mentions Qalä'id al-iqyān by al-Fath b. Khāqān in his work; therefore, the former was composed after the latter was completed. See Muhammad b. 'Iyāḍ, al-Ta'rīf (2009), 97. 
Another author who wrote about 'Iyāḍ was Ibn Bashkuwāl (d. 578 H/1183 CE) in his celebrated biographical dictionary of Andalusi 'ulamā', al-Ṣila ("The Continuation”). ${ }^{25}$ Ibn Bashkuwāl was from Córdoba and studied first in his native town and then in Seville. After completing his studies, he was appointed qā a district in the region of Seville, and later became involved in teaching and writing. Al-Sila includes nearly 1,600 biographical entries, including those of various women 'ulamā', and in it Ibn Bashkuwāl gives various pieces of information about 'Iyāọ, such as his name and origins. He differentiates between Andalusis and "the foreigners" (min al-ghurabā') and describes 'Iyāọ as the latter, and records the reasons for 'Iyāḍ's move to al-Andalus (from Ceuta): to study. He also details in which cities in al-Andalus 'Iyāọ received his education and the teachers responsible for educating him, and gives information about his personality and his time in office as qā the teacher and Ibn Bashkuwāl the student, although it seems that the former taught the latter only a little ${ }^{26}$ - and, finally, the dates of his birth and death. The source of this information was 'Iyāḍ himself, as Ibn Bashkuwāl records. The length of the description of his teacher - which is only 22 lines long in the Beirut edition, and therefore neither very short nor very long - is not much different compared to other entries in his dictionary. However, this concise and rather dull portrait is typical of biographical literature; thus, the information Ibn Bashkuwāl conveyed about 'Iyāọ was included in later biographies, not only in al-Andalus and the Maghrib but also in the Mashriq, as I will argue below.

A little later, Abū Ja far al-Dabbī (d. 599 H/1203 CE), a traditionist and a writer from Lorca, conveyed 'Iyāḍ’s biography in his dictionary, Bughyat al-multamis $f i$ tārīkh rijāl ahl al-Andalus ("The Wish of the One Who Searches for the History of the Men of al-Andalus"). ${ }^{27}$ This work, which contains around 1,600 biographies, was intended to be a continuation (dhayl) of Abū 'Abd Allāh al-Ḥumaydī's (d. 488 H/1095 CE) Jadhwat al-muqtabis fi dhikr wulāt al-Andalus ("The Torch for the One

25 On Ibn Bashkuwāl, see Ibn al-Abbār, al-Mu jam (2011), 115-117; Ibn al-Abbār, al-Takmila (2011), 1: 459-462. See also Ávila, “Ibn Bashkuwāl”, $E P^{3}$. On 'Iyāḍ’s biography, see Ibn Bashkuwāl, al-Ṣila (1989), 2: 660-661. According to the end of part one of this work, Ibn Bashkuwāl finished the compilation on 1 Jumādā I 534 H/24 December 1139 CE. However, since some dates in the text appear after this date, it is believed that he continued writing after that (cf. Ibn Bashkuwāl, al-Ṣila [1989], 1: 15-17).

26 Ibn Bashkuwāl would rather get information about 'ulamā' from 'Iyāḍ and compiled his biographical dictionary. See Ibn al-Abbār, al-Takmila (2011), 1: 461.

27 On al-Ḍabbī, see Ibn al-Abbār, al-Takmila (2011), 1: 188-189. On 'Iyāḍ’s biography, see alDabbī, Bughyat al-multamis (1997), 383-384. 
Who Lights the Story of the Governors of al-Andalus”). ${ }^{28}$ Al-Dabbī spent most of his life in Murcia although he also traveled to numerous other places, including various towns in the North Africa and Mecca, for the hajj. He was taught by many teachers in the town in which he stayed, among whom were Ibn 'Ubayd Allāh (d. late 6th/12th century?) and Ibn Bashkuwāl. The former made al-Ḍabbī listen to hadith in Ceuta, and the latter gave him authorization (ijāza) for something - although there is no specific description for what. In view of this situation, it is likely that his information on 'Iyāọ originated with some of al-Ḍabbī's teachers. Al-Dabbī's text focuses on enumerating the scholars who had taught 'Iyāọ hadìth; as a result, the list of 'Iyāḍ's teachers given by al-Ḍabbī is longer than that provided by Ibn Bashkuwāl. Al-Ḍabbī describes 'Iyāọ as an expert ('ārif) and a man of letters (adīb), in addition to being a jurist and a hadìth scholar. He mentions the title of 'Iyāḍ's work on the terminology of hadìth as being al-Ilmā' ilā ma 'rifat ușūl al-riwāya wa-taqyīd al-samā' ("The Allusion to the Knowledge of the Principles of the Transmission and the Fixing of Audition"), which is new information compared to the entry in Ibn Bashkuwāl. He received information regarding this book from one Abū Muhammad b. 'Ubayd Allāh; it is likely that this person and his similarly-named teacher are one and the same person. Thus, his information on 'Iyāḍ is more detailed than that provided by Ibn Bashkuwāl, probably as result of his journey to Ceuta - 'Iyāḍ’s native town - where he was taught.

Ibn al-Abbār (d. 658 H/1260 CE), a well-known historian, traditionist, littérateur, and poet from Valencia, also wrote a biography of 'Iyāḍ. After extensive study under many scholars including a Mālikī jurist, historian, orator and poet from Murcia, Ibn Sālim al-Kalā'ī (d. 634 H/1237 CE), ${ }^{29}$ Ibn al-Abbār was employed as a secretary by the Almohad governors of Valencia. When the city was conquered by James I of Aragon (r. 1213-1276) in 1238, Ibn al-Abbār left for Tunis, where he was appointed to the chief chancellery of the Hafșids, who ruled Ifrìqiya from $627 \mathrm{H} / 1229 \mathrm{CE}$ to $982 \mathrm{H} / 1574 \mathrm{CE} .^{30}$

Ibn al-Abbār is perhaps most famous as the author of al-Takmila li-kitāb alșila ("The Supplement of al-Ṣila"), a sequel to Ibn Bashkuwāl's biographical dictionary al-Ṣila that his teacher, Ibn Sālim al-Kalā'̄i had persuaded him to write. However, Ibn al-Abbār did not include an entry on 'Iyāọ in it, because the latter has a notice in al-Ṣila, as mentioned above. Instead, Ibn al-Abbār recorded 'Iyāọ

28 Al-Dabbī, Bughyat al-multamis (1997), 11. Regarding the dhayl in the historiography of alAndalus, see Farah 1968, 16.

29 Pellat, "al-Kalācī”, $E I^{2}$.

30 Ávila, "Ibn al-Abbār", $E P^{3}$. His life was full of ups and downs; finally he was killed in Tunis, and his corpse, books, poetry, and diplomas all were burned together. 
in another biographical dictionary, one dedicated to the students of the celebrated traditionist Abū 'Alī al-Ṣadafĩ and entitled al-Mu 'jam fì așḥāb al-qāộ̀ alimām Abì 'Alì al-Șadafì ("The Dictionary of the Companions of the qāộ and imām Abū 'Alī al-Șadafî”). ${ }^{31}$ The article on 'Iyāọ includes his family's origin, his teachers in Córdoba, and details of his meetings with al-Ṣadafì, in addition to the many works 'Iyāḍ studied under him. There is further information on 'Iyāḍ's teachers and his education, along with Ibn al-Abbār's praise for him, his works, and his career, as well as the dates of his birth and death, and his poem. The biography ends with a "hadìth musalsal", which was transmitted via al-Ṣadafĩ and 'Iyāọ to Ibn al-Abbār (the author). ${ }^{32}$ Ibn al-Abbār would have been well aware of the works of both 'Iyāọ and Ibn Bashkuwāl; thus, his detailed information - which is much longer than that provided by Ibn Bashkuwāl - seems to depend upon 'Iyāộs alGhunya and/or Muhammad's al-Ta 'rîf, and al-Șila, judging from the wording, although Ibn al-Abbār does not mention them directly. Meanwhile, it is noteworthy that Ibn al-Abbār mentions another work by 'Iyāọ relating to gharīb al-ḥadìth (a tradition from only one Companion, or from a single man), known as Mashäriq al-anwār 'alā șiḥạh al-āthār ("The Shining Lights on the Correct Prophetic Traditions”), along with a poem by Abū 'Amr b. al-Ṣalāḥ, ${ }^{33}$ in praise of it. Ibn al-Abbār also includes a poem by 'Iyād, which is almost identical to those employed in alFatḥ b. Khāqān's Qalā'id al-iqyān, but this one was conveyed to Ibn al-Abbār through 'Iyāọ’s student Abū 'Abd Allāh b. Zarqūn and the author's own teacher, Ibn Sālim al-Kalā'̄i.

Incidentally, a number of hagiographies were compiled in the Maghrib around this time. However, as Halima Ferhat has indicated, none of the hagiographers, not even Ibn al-Zayyāt al-Tādilī (d. 627 H/1229-30 CE or 628 H/1230-1 CE) - who would have been most likely to record 'Iyāọ in his hagiography - mention

31 Ibn al-Abbār, al-Mu jam (2011), 366-370. We have no information about when he finished this work. Ibn al-Abbār compiled it when he knew that 'Iyāḍ wrote the biographical dictionary of the teachers of 'Iyāọ's teacher al-Ṣadafî. Then, he decided to compile this biographical dictionary of al-Ṣadafì's students (Ibn al-Abbār, al-Mu jam [2011], 21).

32 Hadith musalsal is applied when the transmitters in an isnād have a similar situation. For example, they use the same words, or are of the same type, or come from the same place. See Robson, "Hadith", $E I^{2}$.

33 Abū 'Amr b. al-Șalāḥ, also known as Ibn al-Șalāḥ al-Shahrazūrī (d. 643 H/1245 CE), was a Shāfi 'i jurist and traditionist from a village in the Irbil district (Robson, "Ibn al-Ṣalāḥ", $E I^{2}$ ). According to Ibn al-Abbār's another work, Ibn al-Șalāḥ read this book and use it constantly. Cf. Ibn al-Abbār, al-Muqtạ̣ab (1989), 86. 
'Iyāḍ. Al-Tādilī only mentions the latter's name when he records a poem by alShāfi'ī (d. 204 H/820 CE) that 'Iyāọ had conveyed. ${ }^{34}$

After Ibn al-Abbār, the next writer to provide details about 'Iyāḍ was a polymath, historian, and vizier of Nașrid Granada, Ibn al-Khațīb (d. 776 H/1374-5 CE, probably 1374), in his compendium on that town entitled al-Ihạța fi akhbār Gharnāta ("The All-embracing Work on Reports about Granada"). ${ }^{35}$ In this work, Ibn al-Khatịib relates the history of Granada and provides around 500 biographies of various famous people who had some sort of relationship with the town; these include kings, amìrs, viziers, quạdīs, 'ulamā', and Șūfìs. Compared to earlier examples, Ibn al-Khațīb's biography of 'Iyāḍ is much more detailed, but his information consists almost entirely of citations and extracts from Muhammad's alTa'riff, ${ }^{36}$ along with a poem conveyed by al-Fatḥ b. Khāqān and others (ghayrhu). However, Ibn al-Khațīb essentially ignored the political events in which 'Iyāḍ had taken part, unlike Muhammad, who wrote about them a certain amount of detail.

Subsequently, a qāọī of Nașrid Granada from Málaga, Abū al-Ḥasan alBunnāhī (formerly known as al-Nubāhī, d. the end of the 8th/14th century) included 'Iyāḍ in his biographical dictionary of the qādīis of al-Andalus, al-Marqaba al-'ulyā fi man yastahiqq al-qa $\mathbf{a} \bar{a}$ ' wa-l-fatyā ("The Supreme Watchtower about Those Who Deserve the Judgeship and Issuing Legal Opinions [Muftiship]"). ${ }^{37}$ In his description of 'Iyād, he cites Ibn Bashkuwāl almost verbatim, although he also conveys the new information that 'Iyāḍ lived in Málaga for a while and had property there. Al-Bunnāhī states that this information was mentioned by 'Iyāḍ's descendant (hafid) in the section which the latter compiled in "the introduction" (al-ta' riff) to 'Iyād and his works, information, and sermons. ${ }^{38}$ This "introduction" probably refers to al-Ta'rîf by Muhammad - although technically he was his son rather than just a descendant - and it is likely that al-Bunnāhī could access this information because he was from Málaga.

As such, from the above it can be stated that all the various biographies of 'Iyād that were composed in al-Andalus and the Maghrib were based primarily

34 Al-Tādilī, al-Tashawwuf (2010), 92-93. See also Ferhat 2014, 123-124.

35 Vidal-Castro, “Ibn al-Khațīb, Lisān al-Dīn”, $E I^{3}$. On 'Iyāḍ̣'s biography, see Ibn al-Khațīb, alIhāṭa (2003), 4: 188-194.

36 On citing Ibn al-Khațīb, he said "min kitāb waladihi fì ma'äthirihi, wa-huwa kunnāsh nabīh" (from his son's book on his exploits, and it is an outstanding booklet) and "qāla waladuhu fi ta'lifihi al-nabil" (his son said in his noble work). Thus, he was familiar with al-Ta'rif, although he did not mention the title. See also Muhammad b. 'Iyāḍ, al-Ta'rīf (2009), lām.

37 Carmona, "al-Nubāhī", $E I^{2}$.

38 Al-Bunnāhī, al-Marqaba (1995), 132-133. Muhammad also mentioned this property; Muhammad b. 'Iyāọ, al-Ta'rīf (2009), 98. 
on three originals: those by Muḥammad b. 'Iyāḍ, Ibn Bashkuwāl, and al-Fatḥ b. Khāqān.

Tab. 1: Maghribi and Andalusi sources

\begin{tabular}{|c|c|c|c|c|c|}
\hline $\begin{array}{l}\text { Author } \\
\text { (year of death) }\end{array}$ & Birthplace & Source & $\begin{array}{l}\text { Reference for the } \\
\text { source }\end{array}$ & Poem & $\begin{array}{l}\text { Mention } \\
\text { of } \\
\text { al-Shifä' }\end{array}$ \\
\hline $\begin{array}{l}\text { al-Fatḥ b. Khāqān } \\
\text { (529 H/1134 CE) }\end{array}$ & $\begin{array}{l}\text { Jaén or Se- } \\
\text { ville }\end{array}$ & $\begin{array}{l}\text { Qalāiid al-iqyān } \\
\text { (2010), 683-691 }\end{array}$ & 'Iyāọ & $\bigcirc$ & \\
\hline $\begin{array}{l}\text { Muḥammad b. 'Iyāḍ } \\
\text { (575 H/1179-80 CE) }\end{array}$ & Ceuta & al-Ta'rīf (2009) & $\begin{array}{l}\text { 'lyāḍ and the oth- } \\
\text { ers }^{39}\end{array}$ & $\bigcirc$ & $\bigcirc$ \\
\hline $\begin{array}{l}\text { Ibn Bashkuwāl } \\
\text { (578 H/1183 CE) }\end{array}$ & Córdoba & $\begin{array}{l}\text { al-Șila (1989), } \\
2: 660-661\end{array}$ & 'lyāọ & & \\
\hline $\begin{array}{l}\text { al-Ḍabbī } \\
\text { (599 H/1203 CE) }\end{array}$ & Lorca & $\begin{array}{l}\text { Bughyat al-multa- } \\
\text { mis (1997), 383- } \\
384\end{array}$ & His teacher & & \\
\hline $\begin{array}{l}\text { Ibn al-Abbār } \\
\text { (658 H/1260 CE) }\end{array}$ & Valencia & $\begin{array}{l}\text { al-Mujam (2011), } \\
\text { 366-370 }\end{array}$ & $\begin{array}{l}\text { Muḥammad b. } \\
\text { 'lyāḍ? or 'lyāḍ? } \\
\text { lbn Bashkuwāl? }\end{array}$ & $\bigcirc$ & \\
\hline $\begin{array}{l}\text { Ibn al-Khațīb } \\
\text { (776 H/1374-5 CE) }\end{array}$ & Granada & $\begin{array}{l}\text { al-Ihātạ (2003), } \\
\text { 4: 188-194 }\end{array}$ & $\begin{array}{l}\text { Muḥammad b. } \\
\text { 'lyāọ, } \\
\text { al-Fatḥ b. Khāqān }\end{array}$ & $\bigcirc$ & $\bigcirc$ \\
\hline $\begin{array}{l}\text { al-Bunnāhī (end of } \\
\text { 8th/14th century) }\end{array}$ & Málaga & $\begin{array}{l}\text { al-Marqaba } \\
\text { (1995), 132-133 }\end{array}$ & Ibn Bashkuwāl & & \\
\hline
\end{tabular}

\section{2 'yāọ in the Mashriqi sources ${ }^{40}$}

Of the Mashriqi sources that relate the biography of 'Iyāḍ, the earliest is 'Imād alDīn al-Ișfahānī's (d. 597 H/1201 CE) Kharīdat al-qașr wa-jarīdat al-'așr ("The Pearl-like Virgin of the Castle and the Register of the People of the Age"), which was completed in $573 \mathrm{H} / 1178 \mathrm{CE}{ }^{41}$ 'Imād al-Dīn was a kātib - chancery official

39 See also footnote 21.

40 For further information on the sources and authors examined here, see Guo 2010, 448-453.

41 Richter-Bernburg 2014, 29-51. He was known to have received favors from the Zangid ruler Nūr al-Dīn b. Zangī (r. 541-569 H/1146-1174 CE) and the Ayyūbid sultan Ṣalāḥ al-Dīn b. Ayyūb (r. 569-589 H/1174-1193 CE). 
and court poet - and historian who originated from Isfahan, and his aforementioned text is a vast anthology of the works of various 6th/12th-century poets that was inspired by the prolific author Abū al-Manșūr al-Tha'ālibỉ’s (d. 429 H/1038 CE) Yatìmat al-dahr fi mahāsin ahl al-'aṣr ("The Matchless Peal of Time on the Beautiful Achievements of the People of the Age"). The poets included in Kharidat al-qașr all lived in the Islamic world. In compiling his list of Maghribi and Andalusi poets, 'Imād al-Dīn mainly referenced and cited those found in alFatḥ b. Khāqān's Qalā'id al-iqyān. ${ }^{42}$ Such is the case in the entry on 'Iyāḍ, although he made a significant error in both the date and place of 'Iyāḍ's death, stating that it was "at Fez in AH 543" ${ }^{43}$ 'Imād al-Dīn's words are almost identical to those of al-Fath b. Khāqān with changing the order of the text, although he excludes some letters ( $r a s \bar{a}$ 'il) that are found in the entry on 'Iyād in Qalä'id aliqyān. As such, because they were ignored in 'Imād al-Dīn's source, Qalā'id aliqyān, 'Iyāḍ's education and subsequent career are also not described in Kharīdat al-qașr. It is worth noting that the anthology of poetry and works was the first text from the Mashriq to refer to 'Iyāḍ as well as the Islamic West, and that it was composed only thirty years after his death.

After 'Imād al-Dīn, Jamāl al-Dīn Abū al-Ḥasan 'Alī al-Qifṭī - also known as Ibn al-Qifțī (d. 646 H/1248 CE) - a historian from Qifț, in Upper Egypt, included 'Iyāḍ in Inbāh al-ruwāt 'alā anbāh al-nuḥāt ("The Awaking of the Transmitters on the Illustriousness of Grammarians"), a biographical dictionary of members of the literati. ${ }^{44}$ Although al-Qifți does not detail his sources, the wording indicates that he employed Ibn Bashkuwāl, albeit with some alterations; for example, he omits the names of 'Iyāḍ's teachers, which are mentioned by Ibn Bashkuwāl. He describes 'Iyāḍ as an 'ālim who gathered many hadìths and a qāḍì, in addition to recording 'Iyāḍ’s works, such as Sharh khabar Umm Zar' ("Commentary on Tradition of Umm Zar"), Mashāriq al-anwār, and Tamām al-mu'lim fi sharh kitāb

42 'Imād al-Dīn, Kharīdat al-qașr (1966-72), 1: kāfbā'.

43 'Imād al-Dīn, Kharīdat al-qașr (1966-72), 3: 501-505.

44 Dietrich, "Ibn al-Kịț̣̂”, $E I^{2}$. His father was a deputy to the chancellor (al-qāḍī al-fāḍil) of Șalāh al-Dīn. Al-Qifți himself was in charge of the dīwān of the finances of Șalāh al-Dīn’s son, al-Malik al-Ẓāhir Ghāzì (r. 589-613 H/1193-1216 CE) and of his successor, and then finally appointed vizier. According to the editor of Inbāh al-ruwāt, although there is no information about the beginning or completion of writing, the work must have been started by $626 \mathrm{H} / 1228-9 \mathrm{CE}$ and the copy of this edition finished in 638 H/1240-1 CE. See al-Qifți, Inbāh al-ruwāt (1986), 1: 27. On 'Iyāḍ’s biography, see al-Qifțī, Inbāh al-ruwāt (1986), 2: 363-364. 
Muslim ("Completeness of The Teacher. Commentary on the Book by Muslim"). ${ }^{45}$ As such, al-Qifți’s work can be considered as the first of the Mashriqi sources to contain a "proper” biography of 'Iyāḍ.

The next text to refer to 'Iyāọ was al-Nawawī's biographical dictionary of famous men. ${ }^{46}$ Muhỵì al-Dīn al-Nawawī (d. 676 H/1277 CE) was a Shāfi 'ì jurist from Nawā, south of Damascus, and in his Tahdhīb al-asmā' wa-l-lughāt ("An Account of Names and the Languages") the description of "Iyāḍ copies that of Ibn Bashkuwāl almost verbatim and openly states it was the source. Although neither he nor al-Qifți mention 'Iyāḍ’s teachers, he does say that 'Iyāọ was highly skilled in hadith scholarship, jurisprudence, and Arabic. Before compiling his biographical dictionary, al-Nawawī had compiled a work on the positive laws (furū'al-fiqh) of the Shāfi 'ī school, entitled Raw ḍat al-țālibīn wa- 'umdat al-muftīn ("Students' Garden and Muftis' Support"), and he referred to 'Iyāḍ's al-Shifä' in the "Kitāb alridda" ("The Book of Apostasy") of Rawdat al-țālibinn. ${ }^{47}$ Thus, it is clear that alShifā', the most well-known of all 'Iyāḍ's works, must have been brought to the Mashriq before $669 \mathrm{H} / 1270 \mathrm{CE}$ - that is, the date when al-Nawawi was said to be finished compiling his work - even though he did not mention any of 'Iyāḍ's works in his biography.

The next text to relate the life of 'Iyāḍ was Ibn Khallikān's (d. 681 H/1282 CE) famous biographical dictionary Wafayāt al-a'yān wa-anbā' abnā' al-zamān ("Biographies of Deceased Notable People and History of the Sons of the Epoch"). ${ }^{48}$ He compiled this dictionary in 672 H/1273-4 CE, and it contains details of 'Iyāḍ's names, education, and works, a partial citation from Ibn Bashkuwāl - although it omits his teachers' names - some poems, an outline of a description from Ibn al-Abbār, dates of his birth and death, and an explanation of proper nouns included in this biography. He mentions 'Iyāḍ’s works, including Ikmāl al-mu 'lim,

45 Sharh khabar and Tamām al-mu 'im refer to 'Iyāḍ's Bughyat al-rā'id li-mā fi ḥadīth Umm Zar' and Ikmäl al-mu'lim fi sharh Muslim respectively. For his works and their outlines, see Serrano Ruano 2009, 417-433.

46 Heffening, “al-Nawawī”, $E I^{2}$. On 'Iyāḍ’s biography, see al-Nawawī, Tahdhīb al-asmā̄' (n.d.), sec. 1, part 2, 43-44.

47 Al-Nawawī, Rawdat al-țāibīn (1985), 10: 70. On the date of compilation of this work, see alNawawī, Rawḍat al-țālibīn (1985), 12: 316.

48 Ibn Khallikān was from Irbil, in Iraq, and after studying in Aleppo and Damascus he was

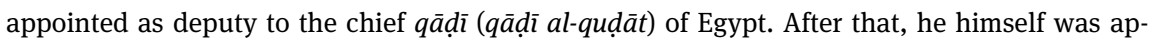
pointed chief $q \bar{a} d \grave{\imath}$ of Damascus by two Mamlūk sultans, Baybars I (r. 658-676 H/1260-1277 CE) and Qalāwūn (r. 678-689 H/1279-1290 CE). See Wedel, “Ibn al-Khallikān”, EI . For 'Iyāọ’s biography, see Ibn Khallikān, Wafayāt al-a yān (1977-78), 3: 483-485. 
Mashāriq al-anwār, and al-Tanbīhāt ("The Admonition"), ${ }^{49}$ along with his poems that were conveyed by his son and 'Imād al-Dīn and which had not been cited by the Mashriqi biographers previously (with the exception of 'Imād al-Dīn, of course). Moreover, Ibn Khallikān states that 'Iyāọ composed "good poetry" (shi'r hasan), a statement that had never, as far as we know, been made before. The description of 'Iyāọ by Ibn Khallikān was synthetic, as the previously separate components - the biographical description from Ibn Bashkuwāl and the poems from the anthologies and the monograph - were combined.

Shams al-Dīn al-Dhahabī (d. 748 H/1348 CE) - a widely respected historian, hadìth expert, and biographer from early Mamlūk Damascus - added to these descriptions..$^{50}$ Al-Dhahabī mentioned 'Iyāḍ in a number of his works, such as Tārīkh al-islām wa-wafayāt al-mashāhīr wa-l-a lām ("The History of Islam and Deaths of the Famous People and Signs") and its abridgements, Tadhkirat alhuffāz ("Memorial of the Qur'ān Masters") and Siyar a 'ām al-nubalā' ("The Lives of Noble Figures"), and others. ${ }^{51}$ His information on 'Iyāḍ, in which he cites Ibn Bashkuwāl, Ibn Khallikān, and Ibn Ḥamāda al-Sabtī, among others, is much more detailed than the preceding biographies, although some of the sources he employed are not named. Even so, the information he cites from Ibn Hamāda, who is believed to have been a student of 'Iyāḍ in Ceuta, is very important because we have hardly any information from Ibn Hamāda, not even from the Maghribi nor Andalusi sources, nor personal information about him. ${ }^{52}$ Al-Dhahabī also gives the names of 'Iyāḍ's five students; this information is the most detailed of all his biographies. ${ }^{53}$ Furthermore, because al-Dhahabī is fulsome in his praise of al-Shifä', calling it 'Iyāḍ's most significant and illustrious work, it is very likely that it was widely circulated and highly regarded in the Mashriq at that time. With al-Dhahabī's work, what may be termed the "Mashriqi biography" of 'Iyāḍ may

49 The full title of al-Tanbīhāt is al-Tanbīhāt al-mustanbita 'alā kutub al-Mudawwana wa-lMukhtalița ("Discovered admonitions on books of al-Mudawwana and al-Mukhtalița"). According to the footnote, another manuscript of Wafayāt al-a $y \bar{a} \bar{n}$ adds al-Shifä' to these titles, although it was omitted in this edition. See Ibn Khallikān, Wafayāt al-a yānn (1977-78), 3: 483, n. 3. 50 Bori, “al-Dhahabī”, $E P^{3}$.

51 Al-Dhahabī, Tārīkh al-islām (1994-2000), 37: 198-201; al-Dhahabī, Tadhkirat al-ḥuffāz (1956-58), 2: 1304-1307; al-Dhahabī, Siyar (1982-88), 20: 212-218. For others, see al-Dhahabī, Tārīkh al-islām (1994-2000), 37: 198, n. 4.

52 He was known as Abū 'Abd Allāh Ibn Ḥamāda al-Sabtī (c. the first half of the 6th/12th century), who wrote a mukhtașar (compendium) of 'Iyāḍ's biographical dictionary, Tartīb almadārik. This work has been published partially as an appendix at the end of the Mohammedia edition of Tartīb al-madārik. On Ibn Ḥamāda, see “Abū 'Abd Allāh b. Ḥamāda” (anonymous).

53 Al-Dhahabī, Tārīkh al-islām (1994-2000), 37: 201; al-Dhahabī, Tadhkirat al-ḥuffāz (1956-58), 2: 1306; al-Dhahabī, Siyar (1982-88), 20: 216. 
be considered essentially cemented from around the middle of the 8th/14th century.

Two other scholars who wrote 'Iyāḍ’s biography are Ibn Faḍl Allāh al- 'Umarī (d. 749 H/1349 CE) and Khalīl b. Aybak al-Ṣafadī (d. 764 H/1363 CE). Ibn Faḍl Allāh al-'Umarī, a famous author and administrator for the Mamlūk state from Damascus, included 'Iyāọ in his encyclopedic work Masālik al-abșār fi mamālik al-amșār ("Routes toward Insight into the Capital Empires"). ${ }^{54}$ He describes 'Iyāọ and praises him, possibly because he had a high opinion of 'Iyāḍ as the author of al-Shifa '. Al-'Umari devoted a paragraph to a description of that book, in addition to recording the personality and biography of 'Iyāḍ, including citations from the descriptions of al-Fatḥ b. Khāqān, Ibn Bashkuwāl, and 'Imād al-Dīn. On the other hand, al-Ṣafadī - a philologist, littérateur, biographer from Șafad who was friends with al-'Umarī - included 'Iyāḍ in his huge biographical dictionary alWāfì bi-l-wafayāt ("Complete Collection of Biographies of the Deceased"). Within it are recorded 'Iyāḍ's dates of birth and death, his career as a qāộ̄ in Ceuta and Granada - this description seems to depend upon that of Ibn Bashkuwāl - a poem in praise of 'Iyāọ by the jurist Abū al-Ḥasan b. Hārūn al-Mālaqī, a list of his works, and his poetry. ${ }^{55}$ What is particularly significant is that al-Safadī wrote that he studied al-Shifā' ' under his teacher Ibn Sayyid al-Nās (d. 734 H/1334 CE) in Cairo in Ramadāan 729 (June-July 1329). Moreover, he lists the transmitters of this book (isnād), going back to 'Iyāọ himself, which demonstrates the work's dissemination. ${ }^{56}$

54 Salibi, "Ibn Faḍl Allāh al-'Umarī”, $E I^{2}$. On 'Iyāḍ̂’s biography, see al-'Umarī, Masālik al-abșār (2010), part 5 in vol. 3: 349-352.

55 Rosenthal, “al-Ṣafadī”, $E I^{2}$. On 'Iyāḍ’s biography, see al-Ṣafadī, al-Wāfi (2008-10), 23: 428431. On Ibn Hārūn al-Mālaqī, see Ibn 'Askar/Ibn Khamīs, A 'lām Mālaqa (1999), 307-309.

56 Al-Șafadī, al-Wāfi (2008-10), 23: 430-431. According to al-Șafadì’s isnād, Ibn Sayyid al-Nās reported it from Abū al-Ḥasan Muhammad b. al-Ḥasan (or al-Ḥusayn) b. 'Atīq b. Rashīq in Cairo in 677 H/1278-9 CE, and the latter reported it from Abū 'Abd Allāh b. Muhammad b. Jubayr who reported it from Abū 'Abd Allāh Muhammad b. 'Īsā al-Tamīmī. Ibn Sayyid al-Nās was a biographer of the Prophet, traditionist, Shāfi 'i jurisprudent from Cairo, although he was descended from a distinguished scholarly family in Seville (Pavlovitch, "Ibn Sayyid al-Nās", $E P^{3}$ ). Ibn Rashīq (d. 680 H/1281-2 CE) was known as 'Ilm al-Dīn, a Mālikī qā ḍi of Alexandria (Ibn Farhūn, al-Dībāj [2005], 2: 255-256; al-Ṣafadī, al-Wāfi [2008-10], 3: 16). Abū 'Abd Allāh b. Jubayr is probably the famous Andalusi traveler and writer Ibn Jubayr (d. 614 H/1217 CE), although correctly, his kunya is not Abū 'Abd Allāh, but Abū al-Ḥusayn. According to Ibn Sayyid al-Nās, Ibn Rashīq reported it from Ibn Jubayr in 609 H/1212-3 CE (Ibn Sayyid al-Nās, 'Uyūn al-athar [1993], 2: 417). Furthermore, Ibn Jubayr's teacher, Muhammad b. 'Īsā, is a grandson of aforementioned 'Iyāọ's teacher Muḥammad b. 'Īsā (Ibn al-Abbār, al-Takmila [2011], 2: 303, 379). 
In that period, various historians - such as Abū al-Fidā' (d. $732 \mathrm{H} / 1331 \mathrm{CE}$ ), Ibn al-Wardī (d. 749 H/1349 CE), al-Yāfi'ī (d. 768 H/1367 CE), and Ibn Kathīr (d. $774 \mathrm{H} / 1373 \mathrm{CE}$ ) - also included 'Iyāọ in the obituaries contained within their chronicles. ${ }^{57}$ Although they add nothing new, it must be pointed out that they tend to describe 'Iyāọ as a traditionist and man of letters who composed good poetry. Moreover, three of the historians mention the following works by 'Iyād: Mashāriq al-anwār, Ikmāl al-mu 'lim, and al-Shifā'. The fourth, Abū al-Fidā', only mentions Mashāriq al-anwār and Ikmāl al-mu lim.

The final writer to be examined is Ibn Farhūn (d. 799 H/1397 CE), who also compiled a biographical dictionary. ${ }^{58} \mathrm{He}$ was from an Arab family that traced its origins to the Quraysh and which had settled in al-Andalus but later returned to Medina, via Tunisia. His al-Dībāj al-mudhahhab fìma'rifat a yān 'ulamā' al-madhhab ("The Gilded Brocade about Knowledge of Notable 'ulamā' of the [Mālikī]

57 Abū al-Fidā' was a prince of Ayyūbids of Hamā, historian, geographer. His universal history, al-Mukhtașar fĩ akhbār al-bashar ("The Concise History of Humanity"), covers the pre-Islamic period up to 729 H/1329 CE (Talmon-Heller, “Abū l-Fidā’”, $E P^{3}$ ). He wrote about 'Iyāḍ's name, birth, qualities as an 'ālim such as imām, hăfiz, and faqīh, etc., and his works Ikmāl al-mu'lim (although he mistakenly refers to it as al-Ijmāl, something that could have been a mistake by a copyist) and Mashāriq al-anwār (Abū al-Fidā', al-Mukhtașar [1998-99], 3: 32). Zayn al-Dīn Ibn alWardī was a Shāfi'i jurist, philologist, man of letters, historian and poet from Ma'arrat alNu'mān. His work, Tatimmat al-Mukhtașar fi akhbār al-bashar ("Completion of the Concise History of Humanity”), was also known as Tārīkh Ibn al-Wardī ("The History of Ibn al-Wardī”) (Ben Cheneb, "Ibn al-Wardī”, $E I^{2}$ ). In this work, Ibn al-Wardī abridged the above-mentioned chronicle of Abū al-Fidā' and continued it from 729 H/1329 CE to 749 H/1349 CE. Subsequently, his information about 'Iyād almost copies that of Abū al-Fidā'. He also mentions the latter's career as $q \bar{a} d \underline{i}$ of Ceuta and Granada, and his poem (Ibn al-Wardī, Tārīkh [1969], 2: 71). Al-Yāfi'ī was an intellectual and a Șūfī from Yemen. He composed a historical book, Mir'āt al-jinān wa-'ibrat alyaqzān fi ma'rifat mā yu'tabar min hawādith al-zamān ("Mirrors of the Soul and the Observant One's Tears about Knowledge of What is Learned from the Events of the Time"), drawn from Ibn al-Athīr (d. 630 H/1233 CE), Ibn Khallikān, and al-Dhahabī (Geoffroy, "al-Yāfi ī", $E I^{2}$ ). He recorded 'Iyāḍ as one of the most distinguished ḥuffāz and wrote about his teachers, his career as $q \bar{a}$ ḍi of Ceuta and Granada, his works, and his qualities as an 'ālim. He finished the description of 'Iyāọ by citing one of his poems (al-Yāfi' 'i, Mir'āt al-jinān [1970], 3: 282-283). Finally, Ibn Kathīr, one of the best-known historians and traditionists of the Bahri dynasty in Syria, includes 'Iyāḍ in his great history of Islam, al-Bidāya wa-l-nihāya ("The Beginning and the End") (Mirza, "Ibn Kathīr”, $E I^{3}$ ). Ibn Kathīr describes 'Iyāḍ as a qā states "he composed good poetry", although he does not cite any poems specifically (Ibn Kathīr, al-Bidāya [1966], 12: 225).

58 After studying in Medina, Ibn Farhūn travelled to Egypt and Syria, before being appointed a Mālikī qāọī in Medina. See Fadel, "Ibn Farhūn̄", EP . Cf. Aḥmad Bābā, Nayl al-ibtihāj (2004), 1: 15-17. For 'Iyāộ’s biography, see Ibn Farḥūn, al-Dībāj (2005), 2: 36-41. 
School”) is a biographical dictionary of Mālikī jurists, containing around 630 entries, that was inspired by Tartīb al-madārik, a similar dictionary written by 'Iyāọ himself. ${ }^{59}$ Ibn Farhūn also studied al-Shifă', under al-Zubayr b. 'Alī al-Uswānī (d. 748 H/1347 CE), a Qur'ān reciter. ${ }^{60}$ Thus, his description of 'Iyāọ is comparatively long. In order to produce 'Iyāḍ's biography, he gathered all the descriptions found in the various relevant Andalusi and Maghribi sources, and probably the Mashriqi ones as well. While he often used his own words - that is, he did not literally copy the preceding biographer's wording - his account is heavily dependent on Ibn Bashkuwāl and Ibn al-Khațīb, in particular. Thus, Ibn Farhūun has known Ibn al-Khațīb's text al-Iḥăța, which was compiled around the same time, and used it for his description. ${ }^{61}$

Tab. 2: Mashriqi sources

\begin{tabular}{|c|c|c|c|c|c|}
\hline $\begin{array}{l}\text { Author } \\
\text { (year of death) }\end{array}$ & Birthplace & Source & $\begin{array}{l}\text { Reference for the } \\
\text { source }\end{array}$ & Poem & $\begin{array}{l}\text { Mention of } \\
\text { al-Shifa } \bar{a}^{\prime}\end{array}$ \\
\hline $\begin{array}{l}\text { 'Imād al-Dīn al- } \\
\text { Ișfahānī } \\
\text { (597 H/1201 CE) }\end{array}$ & Isfahan & $\begin{array}{l}\text { Kharīdat al-qașr } \\
(1966-72), 3: \\
501-505\end{array}$ & $\begin{array}{l}\text { al-Fatḥ b. } \\
\text { Khāqān }\end{array}$ & $\bigcirc$ & \\
\hline $\begin{array}{l}\text { al-Qifțī } \\
(646 \text { H/1248 CE) }\end{array}$ & $\begin{array}{l}\text { Qifț (Upper } \\
\text { Egypt) }\end{array}$ & $\begin{array}{l}\text { Inbāh al-ruwāt } \\
\text { (1986), 2: 363- } \\
364\end{array}$ & Ibn Bashkuwāl? & & \\
\hline $\begin{array}{l}\text { al-Nawawī } \\
(676 \mathrm{H} / 1277 \mathrm{CE})\end{array}$ & $\begin{array}{l}\text { Nawā } \\
\text { (Damascus) }\end{array}$ & $\begin{array}{l}\text { Tahdhīb al-asmā' } \\
\text { (n.d.), sec. 1, part } \\
2,43-44\end{array}$ & Ibn Bashkuwāl & & $(\bigcirc)$ \\
\hline
\end{tabular}

59 Ibn Farḥūn, al-Dībāj (2005), 1: 21-23.

60 Aḥmad Bābā, Nayl al-ibtihāj (2004), 1: 16. Cf. Ibn Farḥūn, al-Dībāj (2005), 1: 7.

61 According to the introduction to al-Ihâța by the editor, Ibn al-Khațîb took time to compile his work. It is thought that he started to gather information in $761 \mathrm{H} / 1358-9 \mathrm{CE}$, before his exile to the Maghrib, resumed it after his return in $763 \mathrm{H} / 1362 \mathrm{CE}$, and continued to add to and revise it. It seems that he finished it in $772 \mathrm{H} / 1370-1 \mathrm{CE}$, that is, before crossing over to the Maghrib for the second time. See Ibn al-Khațīb, al-Ihāța (2003), 1: 4. Shihāb al-Dīn al-Maqqarī saw part of a copy of this book in Cairo; according to him, this copy was donated to a khānqā as a waqf on 22 Muharram 768 (28 September 1366). It is thought that the book was introduced to Cairo around this time (al-Maqqarī, Nafh al-țīb [2012], 7: 102-108). Meanwhile, Ibn Farhūn noted the day of the compilation of this dictionary in Sha'bān 761 (June-July 1360) (Ibn Farḥūn, al-Dībāj [2005], 2: 302); it precedes Ibn al-Khațīb's. Thus, it is reasonable to think that Ibn Farhūn also took time to compile his work and consulted to a just-completed description by Ibn al-Khațîb. 


\begin{tabular}{|c|c|c|c|c|c|}
\hline $\begin{array}{l}\text { Author } \\
\text { (year of death) }\end{array}$ & Birthplace & Source & $\begin{array}{l}\text { Reference for the } \\
\text { source }\end{array}$ & Poem & $\begin{array}{l}\text { Mention of } \\
\text { al-Shifä' }\end{array}$ \\
\hline $\begin{array}{l}\text { Ibn Khallikān } \\
\text { (681 H/1282 CE) }\end{array}$ & Irbil (No. Iraq) & $\begin{array}{l}\text { Wafayāt al-acyān } \\
\text { (1977-78), 3: } \\
\text { 483-485 }\end{array}$ & $\begin{array}{l}\text { Ibn Bashkuwāl, } \\
\text { Muḥammad b. } \\
\text { 'Iyāḍ, } \\
\text { 'Imād al-Dīn al- } \\
\text { Ișfahānī, } \\
\text { lbn al-Abbār }\end{array}$ & $\bigcirc$ & \\
\hline $\begin{array}{l}\text { al-Dhahabī } \\
\text { (748 H/1348 CE) }\end{array}$ & Damascus & $\begin{array}{l}\text { Tārīkh al-islām } \\
\text { (1994-2000), 37: } \\
\text { 198-201; } \\
\text { Tadhkirat al- } \\
\text { huffāz (1956-58), } \\
\text { 2: 1304-1307; } \\
\text { Siyar (1982-88), } \\
\text { 20: 212-218 }\end{array}$ & $\begin{array}{l}\text { Ibn Bashkuwāl, } \\
\text { Ibn Ḥamāda, } \\
\text { Ibn Khallikān, } \\
\text { Muḥammad b. } \\
\text { 'lyāọ }\end{array}$ & $\bigcirc$ & $\bigcirc$ \\
\hline $\begin{array}{l}\text { al-'Umarī } \\
\text { (749 H/1349 CE) }\end{array}$ & Damascus & $\begin{array}{l}\text { Masālik al-abșār } \\
\text { (2010), part } 5 \text { in } \\
\text { vol. 3: 349-352 }\end{array}$ & $\begin{array}{l}\text { al-Fatḥ b. } \\
\text { Khāqān, } \\
\text { Ibn Bashkuwāl, } \\
\text { 'Imād al-Dīn al- } \\
\text { Ișfahānī }\end{array}$ & $\bigcirc$ & 0 \\
\hline $\begin{array}{l}\text { al-Ṣafadī } \\
\text { (764 H/1363 CE) }\end{array}$ & $\begin{array}{l}\text { Șafad (No. } \\
\text { Palestine) }\end{array}$ & $\begin{array}{l}\text { al-Wāfí }(2008- \\
\text { 10), 23: 428-431 }\end{array}$ & $\begin{array}{l}\text { Ibn Bashkuwāl?, } \\
\text { his teacher }\end{array}$ & 0 & $\bigcirc$ \\
\hline $\begin{array}{l}\text { Abū al-Fidā' } \\
\text { (732 H/1331 CE) }\end{array}$ & Damascus & $\begin{array}{l}\text { al-Mukhtașar } \\
\text { (1998-99), 3: } 32\end{array}$ & & & \\
\hline $\begin{array}{l}\text { Ibn al-Wardī } \\
\text { (749 H/1349 CE) }\end{array}$ & $\begin{array}{l}\text { Ma'arrat al- } \\
\text { Nu'mān (W. } \\
\text { Syria ) }\end{array}$ & $\begin{array}{l}\text { Tārīkh (1969), 2: } \\
71\end{array}$ & & 0 & $\bigcirc$ \\
\hline $\begin{array}{l}\text { al-Yāfi'ī } \\
(768 \text { H/1367 CE) }\end{array}$ & Yemen & $\begin{array}{l}\text { Mir'āt al-jinān } \\
\text { (1970), 3: 282- } \\
283\end{array}$ & & 0 & $\bigcirc$ \\
\hline $\begin{array}{l}\text { Ibn Kathīr } \\
\text { (774 H/1373 CE) }\end{array}$ & $\begin{array}{l}\text { Bosra (So. } \\
\text { Iraq) }\end{array}$ & $\begin{array}{l}\text { al-Bidāya (1966), } \\
\text { 12: } 225\end{array}$ & & & $\bigcirc$ \\
\hline
\end{tabular}




\begin{tabular}{|c|c|c|c|c|c|}
\hline $\begin{array}{l}\text { Author } \\
\text { (year of death) }\end{array}$ & Birthplace & Source & $\begin{array}{l}\text { Reference for the } \\
\text { source }\end{array}$ & Poem & $\begin{array}{l}\text { Mention of } \\
\text { al-Shifa } \bar{a}^{\prime}\end{array}$ \\
\hline $\begin{array}{l}\text { Ibn Farḥūn } \\
(799 \text { H/1397 CE) }\end{array}$ & Medina & $\begin{array}{l}\text { al-Dībāj (2005), 2: } \\
36-41\end{array}$ & $\begin{array}{l}\text { Muḥammad b. } \\
\text { 'Iyāḍ, } \\
\text { Ibn Bashkuwāl, } \\
\text { lbn al-Khațīb, } \\
\text { Ibn Khallikān } \\
\text { or/and al-Dha- } \\
\text { habī? }\end{array}$ & $\bigcirc$ & $\bigcirc$ \\
\hline
\end{tabular}

\section{The communication of biographical information: A comparison of the Maghribi- Andalusi and Mashriqi sources}

I would now like to summarize how biographical information on 'Iyāḍ was communicated within and between the regions. As mentioned, 'Iyāọ never undertook a rihla to the Mashriq nor went on the hajj, and there is little evidence that he had any Mashriqi students; consequently, it could be expected that he would have had little intellectual influence in the Mashriq at that time. Nevertheless, a number of biographies of 'Iyāḍ were compiled in the Mashriq quite soon after his death, the result of writers believing that his biography was worthy of inclusion in their dictionaries. Yet, which points about his life did they wish to emphasize? To elucidate the main features of their descriptions of 'Iyāḍ, I will highlight two main points: the first is concerned with his poems, or ability as a man of letters, while the second is their focus on his written works, especially al-Shifä'.

The most oft-employed description of 'Iyāḍ was that by Ibn Bashkuwāl, something that was common to both the Maghribi and the Mashriqi biographies. It is perhaps natural that the brief and clear biography written by Ibn Bashkuwāl, a student of 'Iyāọ, became widely utilized. On the other hand, despite 'Iyāọ’s poetry also being often referenced, it is cited primarily by biographers from the Mashriq, in stark contrast with those from the Maghrib who mostly ignored it. As stated above, the first source to contain 'Iyāḍ's poems in the West was al-Fath b. Khāqān's anthology Qalā'id al-iqyān and the first of the Mashriqi sources was also the anthology, Kharīdat al-qașr, by 'Imād al-Dīn, in which all the poems found in Qalā'id al-iqyān are included. Moreover, it appears that this situation came about primarily through citations in Ibn Khallikān's famous biographical dictionary, 
where the flattering phase "[he composed] good poetry" is to be found. ${ }^{62}$ As far as Ibn Khallikān is concerned, his information about 'Iyāḍ's son Muhammad - that he was the "qā dī of Dénia" - probably came from Ibn Dihya’s (d. 633 H/1235 CE) anthology al-Mutrib min ash'är ahl al-Maghrib ("The Delightfulness from the Poetry of the People of the Maghrib") rather than from Qalā'id al-iqyān or Kharidat al-qașr, though he did not mention the former. ${ }^{63}$ Ibn Khallikān may have considered 'Iyād to be a good poet not only because of the quality of the poetry itself but also because it was frequently cited by famous anthologists. ${ }^{64}$ Subsequent biographical sketches also quote the same poem(s), and this resulted in repeated emphasis being placed on 'Iyāḍ’s ability to compose good poetry or as a man of letters in the Mashriq. While in the Maghrib and al-Andalus, 'Iyāḍ's son Muhammad, Ibn al-Abbār, and Ibn al-Khațīb all made use of his poetry, it never became part of his biographical tradition, where he was instead described primarily as a traditionist and jurist.

Secondly, as far as the sources - that were examined in this paper - are concerned, knowledge and appreciation of 'Iyāḍ's most famous work, al-Shifä', can be attested earlier in the Mashriq than in the Maghrib and al-Andalus. At the time of al-Nawaw $\overline{1}$ - that is, around $669 \mathrm{H} / 1270 \mathrm{CE}$ - this text was already in circulation, and it was to become even more highly regarded around the time of al-Dhahabī, that is, the middle of the 8th/14th century. Moreover, Ibn Farhūn stated that "copies of this work spread eastward and westward" (țārat nusakhuhu sharqan wa-gharban), while, more than 150 years later, one of the most prolific Cairene writers of the Middle Ages, Jalāl al-Dīn al-Suyūṭī (d. 911 H/1505 CE), wrote abstracts of the hadìths contained within al-Shifä', in a work entitled Manāhil alșafā' fi takhrïj aḥādìth al-shifā' ("The Pure Fountain about Extract of Hadìths from al-Shifā'”). ${ }^{65}$

As such, was al-Shifä' ignored in the Maghrib and al-Andalus? The answer is, of course, no. While the evidence in the biographical dictionaries is scarce - with

62 Ibn Khallikān, Wafayāt al-a'yān (1977-78), 3: 484.

63 Ibn Dihya al-Kalbī was a poet, philologist, and traditionist, probably from Valencia. He traveled within al-Andalus, and to the Maghrib, North Africa, Egypt, Syria, Iraq, and Persia. After his return to Egypt, he enjoyed the Ayyūbid ruler's favor. His celebrated work, al-Mutrib, is a vast anthology of the poets of the Islamic West, which was compiled in Egypt and dedicated to his royal patron, al-Malik al-Kāmil (r. 615-635 H/1218-1238 CE). Thus, it is likely that Ibn Khallikān had access to this work. See Granja, "Ibn Dihyya”, $E I^{2}$. On 'Iyāḍ's poetry, which was conveyed by his son, see Ibn Dihya, al-Muțrib (1955), 87.

64 Hermosilla refers to one of his poems cited by Ibn Khallikān and highlights that it shows 'Iyāọ's talent in belles-lettres (Hermosilla 1978-79, 161).

65 Serrano Ruano 2009, 426. 
the exception of those by Muhammad and Ibn al-Khațīb -, in order to get a better understanding of the situation it will be useful to shift focus from the topic of biography to that of the veneration of the Prophet Muhammad. In the Islamic West, the veneration of the Prophet Muhammad as an ideal figure had been steadily increasing from the 6 th/12th century. ${ }^{66}$ The origin of this veneration is attributable to Abū 'Alī al-Ṣadafî, who played a significant role in the development of this movement, as he brought from the East a collection of hadiths, alTirmidhì's (d. 279 H/892 CE) al-Shamā'il al-Muhammadiyya ("The Appearance of Muhammad"), and taught it to his many students. ${ }^{67}$

'Iyāḍ was taught this work by al-Șadafî directly, ${ }^{68}$ and so his al-Shifā', based as it is upon the sciences of hadith, can be seen as a product of this movement. Moreover, Ibn Bashkuwāl who was a student not only of 'Iyāọ but also of al-Șadafî, also wrote a similar work, entitled Kitāb al-Qurba ilā Rabb al-'Ālamīn ("The Approach to Lord of Worlds"), and it has been pointed out that this closely resembles part of al-Shifā' ${ }^{\prime}{ }^{69}$ Therefore, the influence of al-Shifä' can be confirmed in the movement of the veneration of the Prophet Muhammad immediately after his compilation. This tradition of composing works venerating the Prophet was continued by Ibn Dihya. On the other hand, as Muhammad al-Hāṭī has shown, a large number of commentaries (sharh) on al-Shif $\bar{a}$ ' were produced in the Maghrib and al-Andalus, the first of which was composed by a Qur'ānic exegete from Marrakesh, Abū al-Ḥasan al-Ḥarrālī (d. 637 H/1239-40 CE or 638 H/1240-1 CE). ${ }^{70}$ Thus, al-Shif $\bar{a}$ ' was widely read by the people of the Maghrib and al-Andalus, including Șūfīs. ${ }^{71}$ However, it is rather odd that al-Bunnāhī, the biographer of 'Iyāḍ, makes no mention of this work even though, according to the later biographer Ahmad Bābā (d. 1036 H/1627 CE), he studied it. ${ }^{72}$ Furthermore, the well-known Maghribi biographer Ibn al-Qāḍi al-Miknāsī (d. 1025 H/1616 CE) is silent about al-Shifă'. ${ }^{73}$

66 Sato 2005, 28-33; Sato 2006, 7.

67 We can understand this situation from many descriptions in Ibn al-Abbār's Mu'jam.

68 'Iyāạ, al-Ghunya (1979), 196.

69 Sato 2005, 28-33.

70 Al-Hāṭi 2015. On al-Ḥarralī, see Ibn al-Abbār, al-Takmila (2011), 3: 415; al-Dhahabī, Siyar (1982-88), 23: 47.

71 Sato 2005, 29-30.

72 Aḥmad Bābā, Nayl al-ibtihāj (2004), 1: 370-371.

73 Ibn al-Qāḍī barely conveys that a famous khațīb from Tlemcen, Ibn Marzūq (d. 781 H/1379

CE) wrote an unfinished commentary on al-Shifa ${ }^{\prime}$, although the former does not mention the author's name of this book (Ibn al-Qāḍī, Jadhwat al-iqtibās [1973-74], 1: 227). 


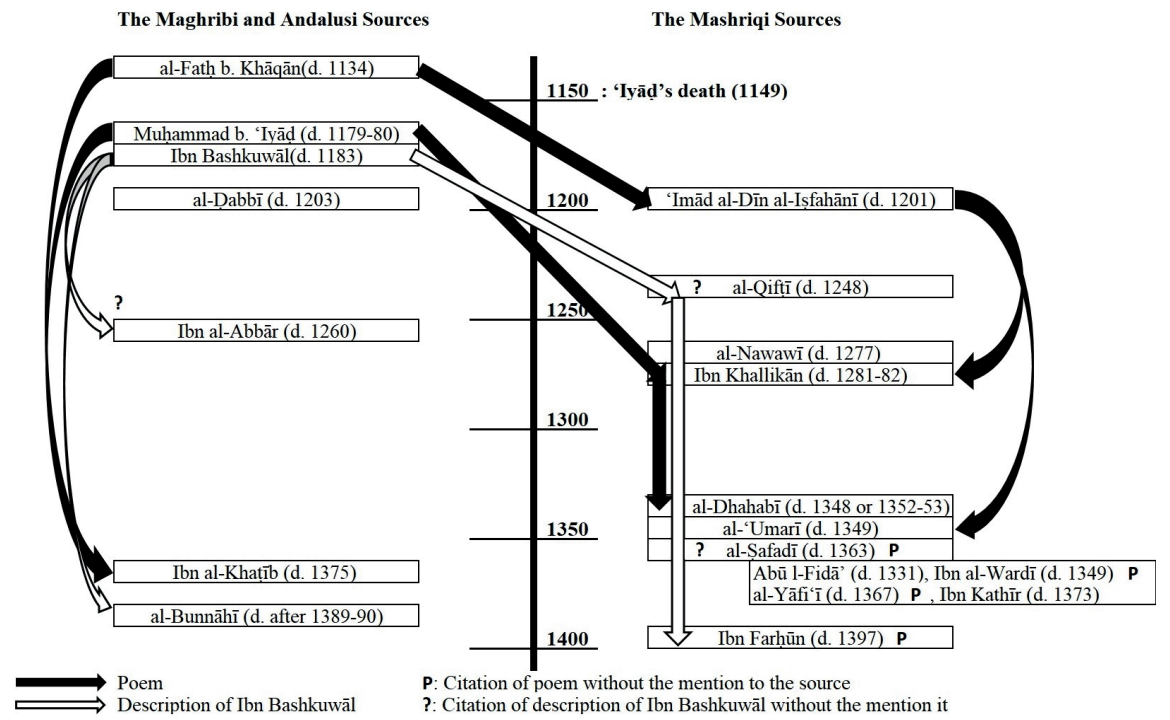

Fig. 1: Communication of biographical information

\section{Conclusion}

Biographies of 'Iyāḍ started to be written soon after his death and continued to be composed for centuries after, not only in the Maghrib and al-Andalus but also in the Mashriq. Significantly, the biographies of 'Iyāḍ written in the Maghrib and al-Andalus are no more detailed than those compiled in the Mashriq. Moreover, the Mashriqi authors took advantage of these biographies soon after they were written. The descriptions of 'Iyād reflect the biographer's interests and the approach to historical compilation followed in each region.

Generally, it seems possible to construct a plausible figure of an 'âlim such as 'Iyād through examining and comparing two or more biographies but, at the same time, it is important to consider how and why the information regarding that figure was conveyed. This is because the way in which information is conveyed differs according to the values and ideas of both the individual biographers and the society in which it was composed. The extent to which this one case-study of 'Iyād reflects a wider trend is a question that can only be answered via further, future studies. 


\section{Bibliography}

\section{Primary sources}

Abū al-Fidā', Ismā'īl ibn 'Alī (1998-1999), al-Mukhtașar fĩ akhbār al-bashar, ed. by Muḥammad Zaynahum Muḥammad 'Azab, Yaḥyā Sayyid Ḥusayn, Muḥammad Fakhrī Wașīf, and Ḥusayn Mu'nis, 4 vols., Cairo: Dār al-Ma'ārif.

Aḥmad Bābā al-Tinbuktī (2004), Nayl al-ibtihāj bi-tațrīz al-Dībāj, ed. by 'Alī 'Umar, 2 vols., Cairo: Maktabat al-Thaqāfa al-Dīniyya.

Al-Bunnāhī, Ibn al-Ḥasan (= al-Nubāhī) (1995), Tārīkh quḍāt al-Andalus aw al-Marqaba al-'ulyā fí man yastaḥiqq al-qạ̣āà wa-l-fatyā, ed. by Maryam Qāsim Tawīl, Beirut: Dār al-Kutub al'Ilmiyya.

Al-Ḍabbī, Aḥmad b. Yaḥyā (1997), Bughyat al-multamis fĩ tārīkh rijāl ahl al-Andalus, ed. by Rūḥiyya 'Abd al-Raḥmān al-Suwayfī, Beirut: Dār al-Kutub al-'Ilmiyya.

Al-Dhahabī, Muḥammad b. Aḥmad (1982-1988), Siyar a'lām al-nubalā', ed. by Shu'ayb Arnā'ūṭ, Kāmil al-Kharrāț et al., 25 vols., Beirut: Mu'assasat al-Risāla.

Al-Dhahabī, Muḥammad b. Aḥmad (1956-1958), Kitāb Tadhkirat al-ḥuffāz, ed. by the Bureau from the Meccan Library Ms. Under the auspices of the Ministry of Education, Government of India, 4 vols. in 2, Hyderabad: The Dairatu'l-Ma'arifi'l-Osmania.

Al-Dhahabī, Muḥammad b. Aḥmad (1994-2000), Tārīkh al-islām wa-wafayāt al-mashāhīr wa-lálām, ed. by 'Umar Tadmurī, 52 vols., Beirut: Dār al-Kitāb al-'Arabī.

Al-Fatḥ b. Khāqān (2010), Qalāìd al-iqyān wa-maḥāsin al-a'yān, ed. by Ḥusayn Yūsuf Kharyūsh, Irbid: 'Ālam al-Kutub al-Ḥadīth.

Ibn al-Abbār al-Quḍā'ī (2011), al-Mu'jam fí aṣhāāb al-qāọī al-imām Abī 'Alī al-Șadafí, ed. by Bashshār 'Awwād Ma'rūf, Tunis: Dār al-Gharb al-Islāmī.

Ibn al-Abbār al-Quḍāī (1989), al-Muqtaḍab min Kitāb Tuhfat al-qādim, ed. by Ibrāhīm al-lbyārī, Cairo - Beirut: Dār al-Kitāb al-Miṣrī - Dār al-Kitāb al-Lubnānī.

Ibn al-Abbār al-Quḍāî (2011), al-Takmila li-kitāb al-ṣila, ed. by Bashshār 'Awwād Ma'rūf, 4 vols., Tunis: Dār al-Gharb al-Islāmī.

Ibn 'Abd al-Malik al-Marrākushī (2012), al-Dhayl wa-l-takmila li-kitābay al-mawșūl wa-l-șila, ed. by lḥsān 'Abbās, Muḥammad b. Sharīfa, and Bashshār 'Awwād Ma'rūf, 6 vols., Tunis: Dār al-Gharb al-Islāmī.

Ibn 'Askar, Abū 'Abd Allāh / Ibn Khamīs, Abū Bakr (1999), A'lām Mālaqa, ed. n.n., Beirut: Dār alGharb al-Islāmī - Rabat: Dār al-Amān li-l-Nashr wa-l-Tawzī'.

Ibn Bashkuwāl (1989), Kitāb al-Șila, ed. by Ibrāhīm al-Ibyārī, 3 vols., Cairo - Beirut: Dār alKitāb al-Miṣrī - Dār al-Kitāb al-Lubnānī.

Ibn Diḥya al-Kalbī (1955), al-Muṭrib min ash'ār ahl al-Maghrib, ed. by Ibrāhīm al-lbyārī, Ḥāmid 'Abd al-Majīd, and Aḥmad Ạ̣mad Badawī, Beirut: Dār al-'Ilm li-l-Jamī'.

Ibn Farḥūn (2005), al-Dībāj al-mudhahhab fĩ márifat a'yān 'ulamāò' al-madhhab, ed. by Muḥammad al-Aḥmadī, 2 vols. in 1, Cairo: Maktabat Dār al-Turāth.

Ibn Kathīr, Ismā'̄il ibn 'Umar (1966), al-Bidāya wa-l-nihāya, ed. n.n., 14 vols. in 7, Beirut - Riyadh: Maktabat al-Ma'ārif - Maktabat al-Nașr.

Ibn Khallikān (1977-1978), Wafayāt al-a'yān wa-anbā' abnā' al-zamān, ed. by lḥsān 'Abbās, 8 vols., Beirut: Dār Șādir.

Ibn al-Khațīb, Lisān al-Dīn (2003), al-Ihāța fí akhbār Gharnāṭa, ed. by Yūsuf 'Alī Ṭawīl, 4 vols., Beirut: Dār al-Kutub al-'Ilmiyya. 
Ibn al-Qāḍī al-Miknāsĩ (1973-1974), Jadhwat al-iqtibās fí dhikr man ḥalla min al-ấām madīnat Fās, ed. n.n., 2 vols., Rabat: Dār al-Manșūr li-l-Ṭibā'a wa-l-Wirāqa.

Ibn Sayyid al-Nās (1993), 'Uyūn al-athar fí funūn al-maghāzī wa-l-shamāil wa-l-siyar, ed. by Ibrāhīm Muḥammad Ramaḍān, 2 vols., Beirut: Dār al-Qalam.

Ibn al-Wardī, Zayn al-Dīn 'Umar (1969), Tārīkh Ibn Wardī, ed. n.n., 2 vols., Najaf: al-Mațba'a alḨaydariyya.

'Imād al-Dīn al-Ișfahānī (1966-1972), Kharīdat al-qașr wa-jarīdat al-'aṣr: Qism shu'arā' al-

Maghrib, ed. by Muḥammad al-Marzūqī, Muḥammad al-'Arūsī al-Muṭ̂ī, and al-Jīlānī b. alḤājj Yaḥyā, 3 vols., Tunis: al-Dār al-Tūnisiyya li-l-Nashr.

'Iyāọ b. Mūsā, Abū al-Faḍl (1979), al-Ghunya, ed. by Muḥammad b. 'Abd al-Karīm, Tunis: al-Dār al-'Arabiyya li-l-Kitāb.

'Iyāọ b. Mūsā, Abū al-Faḍl (1981-1983), Tartīb al-madārik wa-taqrīb al-masālik li-márifat a'lām madhhab Mālik, ed. by Ibn Tāwīt al-Ṭanjī, 'Abd al-Qādir Șị̣rāwī, Muḥammad b. Sharīfa, and Sa'īd Aḥmad A'rāb, 8 vols., Mohammedia - Tetouan: Mațba'at Faḍāla - Mațābi' alShuyūkh.

Al-Maqqarī, Shihāb al-Dīn Aḥmad b. Muḥammad (1980), Azhār al-riyāẹ fĩ akhbār lyāọ, ed. by Sa'īd Aḥmad A'rāb, Muḥammad b. Tāwīt, and 'Abd al-Salām al-Harrās, 5 vols., Mohammedia: Mațba'at Faḍāla.

Al-Maqqarī, Shihāb al-Dīn Aḥmad b. Muḥammad (2012), Naf̣̣ al-țīb min ghuṣn al-Andalus alrațīb, ed. by lḥsān 'Abbās, 8 vols., Beirut: Dār Șādir.

Muḥammad b. 'Iyāọ, Abū 'Abd Allāh (2009), al-Tárīf bi-l-Qāḍī Iyāọ, ed. by Muhammad b. Sharīfa, Marrakesh: al-Mațba'a wa-l-Wirāqa al-Wațaniyya al-Dāwdiyyāt.

Al-Nawawī, Muḥī al-Dīn (1985), Rawḍat al-țālibīn wa-'umdat al-muftīn, ed. by Zuhayr alShāwīsh, 12 vols, Beirut - Damascus - Amman: al-Maktab al-Islāmī.

Al-Nawawī, Muḥyī al-Dīn (n.d.), Tahdhīb al-asmā’ wa-l-lughāt, ed. by Idārat al-Ṭibā'a al-Munīriyya, 4 vols. in 2, Beirut: Dār al-Kutub al-'Ilmiyya.

Al-Qifțī, Jamāl al-Dīn Abū al-Ḥasan 'Alī (1986), Inbāh al-ruwāt 'alā anbāh al-nuḥāt, ed. by Muḥammad Abū al-Faḍl Ibrāhīm, 4 vols., Cairo - Beirut: Dār al-Fikr al-'Arabī - Mu'assasat al-Kutub al-Thaqāfiyya.

Al-Șafadī, Khalīl b. Aybak (2008-2010), Kitāb al-Wāfí bi-l-wafayāt, ed. by Hellmut Ritter, Sven Dedering, lḥsān 'Abbās et al., 30 vols., Beirut: al-Ma'had al-Almānī li-l-Abḥāth al-Sharqiyya.

Al-Tādilī, Ibn al-Zayyāt (2010), al-Tashawwuf ilā rijāl al-tașawwuf wa-akhbār Abū al-'Abbās alSabtī, ed. by Aḥmad al-Tawfīq, Casablanca: Mațba'at al-Najāḥ al-Jadīda.

Al-'Umarī, Ibn Faḍl Allāh (2010), Masālik al-abṣār fĩ mamālik al-amṣār, ed. by Kāmil Salmān alJubūrī, 27 vols. in 15, Beirut: Dār al-Kutub al-'Ilmiyya.

Al-Yāfi' 'î, 'Abd Allāh b. As'ad (1970), Mir'āt al-jinān wa-'ibrat al-yaqzān fí ma'rifat mā yu'tabar min ḥawādith al-zamān, ed. n.n., 4 vols., Beirut: Mu’assasat al-A'lamī li-l-Mațbū'āt.

\section{Secondary sources}

Anonymous (n.d.), “Abū 'Abd Allāh b. Ḥamāda al-Burnusī al-'ālim al-mu'arrikh”, Da'wat alhaqq, 221, http://www.habous.gov.ma/daouat-alhaq/item/5721 (accessed June 9, 2019). Ávila, María Luisa, “Ibn al-Abbār, al-Quḍāī”, Encyclopaedia of Islam, THREE, 2016-4, 116-118. Ávila, María Luisa, “Ibn Bashkuwāl”, Encyclopaedia of Islam, THREE, 2018-1, 87-90. 
Ben Cheneb, M., "Ibn al-Wardī”, The Encyclopaedia of Islam, 2nd ed., 3: 966-967.

Ben Cheneb, M. / Pellat, Ch., "al-Fatḥ b. Muḥammad b. 'Ubayd Allāh b. Khāḳān”, The Encyclopaedia of Islam, 2nd ed., 2: 838.

Bori, Caterina, “al-Dhahabī”, Encyclopaedia of Islam, THREE, 2016-1, 73-80.

Carmona, A., "al-Nubāhī (or, more probably, al-Bunnāhī)", The Encyclopaedia of Islam, 2nd ed., 12: 679.

Cooperson, Michael (2010), “Biographical Literature”, in: R. Irwin, ed., The New Cambridge History of Islam, Vol. 4: Islamic Cultures and Societies to the End of the Eighteenth Century, Cambridge: Cambridge University Press, 458-473.

Dietrich, A., “Ibn al-Ḳifți”, The Encyclopaedia of Islam, 2nd ed., 3: 840.

Eggen, Nora S. (2018), “A book burner or Not? History and myth: Revisiting al-Qāḍī 'lyāọ and the controversies over al-Ghazālī in the Islamic West”, Journal of Arabic and Islamic Studies $18,87-109$.

Fadel, Mohammad, “Ibn Farḥun”, Encyclopaedia of Islam, THREE, 2018-2, 88-89.

Farah, Caesar E. (1968), The Dhayl in Medieval Arabic Historiography, New Haven: American Oriental Society.

Ferhat, Halima (2014), Sabta des origines au XIVe siècle, Rabat: Université Mohammed VAgdal, Publication de la Faculté des Lettres et des Sciences Humaines.

Fierro, Maribel (1994), “The Qāḍī as Ruler”, in: Saber religioso y poder político en el Islam (Actas del Simposio Internacional, Granada, octubre 15-18, 1991), Madrid: Agencia Española de Cooperación Internacional, 71-116.

Fierro, Maribel (2006), “Sobre monedas de época almohade: I. El dinar del Cadí 'lyāḍ que nunca existió. II. Cuándo se acuñaron las primeras monedas almohades y la cuestión de la licitud de acuñar moneda", Al-Qanțara 27, 457-76.

Geoffroy, E., "al-Yāfi 'ī", The Encyclopaedia of Islam, 2nd ed., 11: 236.

Gómez-Rivas, Camilo (2013), “Qāọī 'Iyāọ (d. 544/1149)”, in: Oussama Arabi et al., eds., Islamic Legal Thought: A Compendium of Muslim Jurists, Leiden: Brill, 323-338.

Granja, F. de la, “Ibn Dihya”, The Encyclopaedia of Islam, 2nd ed., 3: 747.

Guo, Li (2010), “History writing”, in: R. Irwin, ed., The New Cambridge History of Islam, Vol. 4: Islamic Cultures and Societies to the End of the Eighteenth Century, Cambridge: Cambridge University Press, 444-457.

Al-Hāțī, Muḥammad (2015), “al-Shifā' bi-ta 'rīf ḥuqūq al-Mușțafā li-l-Qāḍī 'lyāọ ka-matn mursikh li-thaqāfa al-tawassuṭ wa-l-i'tidāl fĩ al-tadayyun al-Maghribī”, https://www.ar-

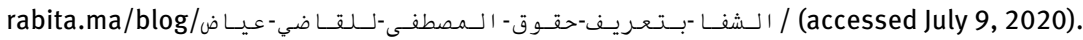

Heffening, W., “al-Nawawī", The Encyclopaedia of Islam, 2nd ed., 7: 1041-1042.

Hermosilla Listerri, María José (1978-1979), “En torno al-Qaḍī 'lyāọ I: Datos Biográficos”, Miscelánea de Estudios Árabes y Hebraicos 17-18, 149-164.

Humphreys, R. Stephen (1991), Islamic History: A Framework for Inquiry, Princeton: Princeton University Press.

Jallāb, Ḥasan (2009), al-Qāḍī lyāẹ, Marrakesh: al-Mațba'a wa-l-Wirāqa al-Wațaniyya.

Jones, Linda G. (2013), “A Case of Medieval Political ‘Flip-Flopping’? Shifting Allegiances in the Sermons of Al-Qadi 'lyad”, in: Franco Morenzoni, ed., Preaching and Political Society: From Late Antiquity to the End of the Middle Ages, Turnhout: Brepols Publishers, 65-110.

Kassis, Hanna (1983), "Qāḍī 'lyāḍ’s Rebellion against the Almohads in Sabtah (A.H.542543/A.D.1147-1148): New Numismatic Evidence”, Journal of the American Oriental Society $103 / 3,505-514$.

Mirza, Younus Y., “Ibn Kathīr, 'Imād al-Dīn”, Encyclopaedia of Islam, THREE, 2016-5, 128-137. 
Pavlovitch, Pavel, “Ibn Sayyid al-Nās”, Encyclopaedia of Islam, THREE, 2019-5, 85-87.

Pellat, Ch., "al-Kalā'ī”, The Encyclopaedia of Islam, 2nd ed., 4: 468.

Richter-Bernburg, Lutz (2014), “'Imād ad-Dīn al-Ișfahānī”, in: Alex Mallett, ed., Medieval Muslim Historians and the Franks in the Levant, Leiden - Boston: Brill, 29-51.

Robson, J., "Hiadīth”, The Encyclopaedia of Islam, 2nd ed., 3: 23-28.

Robson, J., "Ibn al-Șalāḥ”, The Encyclopaedia of Islam, 2nd ed., 3: 927.

Rosenthal, F., "al-Ṣafadī", The Encyclopaedia of Islam, 2nd ed., 8: 759-760.

Salibi, K. S., “Ibn Faḍl Allāh al- 'Umarī”, The Encyclopaedia of Islam, 2nd ed., 3: 758-759.

Sato, Kentaro (2005), The Nativity of the Prophet Muhammad in al-Andalus and al-Maghrib in the 13th - 15th Century, Ph.D. dissertation, The University of Tokyo (in Japanese).

Sato, Kentaro (2006), "Sufi Celebrations of Muhammad's Birthday (al-Mawlid al-Nabawī) and the Ulama's View on it in al-Andalus and al-Maghrib, 1300-1400", The Journal of Sophia Asian studies 24, 7-15.

Serrano Ruano, Delfina (1999), “Los Banū 'lyāḍ, de la caída del imperio almorávid a la instauración de la dinastía nazarí”, in: M. L. Ávila and M. Fierro, eds., Estudios Onomástico-Biográficos de al-Andalus 9, Madrid - Granada: CSIC, 351-406.

Serrano Ruano, Delfina (2004), “Ibn 'Iyāọ al-Sabtī, Abū 'Abd Allāh”, in: Jorge Lirola Delgado and José Miguel Puerta Vílchez, eds., Biblioteca de al-Andalus 3: De Ibn al-Dabbāg a lbn Kurz, Almería: Fundación Ibn Tufayl de Estudios Árabes, 542-544.

Serrano Ruano, Delfina (2009), “'lyāḍ, Abū l-Faḍl”, in: Jorge Lirola Delgado, ed., Biblioteca de al-Andalus 6: De Ibn al-Ŷabbāb a Nubdatat al-'așr, Almería: Fundación Ibn Tufayl de Estudios Árabes, 404-434.

Shaqūr, 'Abd al-Salām (1983), al-Qāẹ̄i lyāẹ al-adīb: al-adab al-maghribī fí ẓill al-Murābițīn, Tangier: Dār al-Fikr al-Maghribī.

Shawwāṭ, al-Ḥusayn b. Muḥammad (1999), al-Qāộ̄ 'lyāọ: 'Ālim al-Maghrib wa-imām ahl alhadīth fĩ waqtihi, Damascus: Dār al-Qalam.

Talmon-Heller, Daniella, “Abū l-Fidā'”, Encyclopaedia of Islam, THREE, 2008-1, 39-40.

Vidal-Castro, Francisco, “Ibn al-Khațīb, Lisān al-Dīn”, Encyclopaedia of Islam, THREE, 2017-5, 116-123.

Warāglī, Ḥasan (1994), Abū al-Faḍl al-Qāọī lyāọ al-Sabtī: Thabt bibliyūjrāfí, Beirut: Dār alGharb al-Islāmī.

Wedel, G., “Ibn al-Khallikān”, Encyclopaedia of Islam, THREE, 2018-5, 91-99. 